\title{
Creativity and Innovation of Artist in Maintaining and Developing the Songah Tradition Art
}

\author{
Ridwan Ridwan ${ }^{\bowtie}$, Tati Narawati, Uus Karwati, Yudi Sukmayadi \\ Universitas Pendidikan Indonesia, Indonesia
}

Submitted: June 30, 2020. Revised: September 29, 2020. Accepted: November 4, 2020

\begin{abstract}
Songah is one of the traditional arts originating from Citengah Village, Sumedang Regency. This art was formed from the creativity and innovation of the people of Citengah Village, Sumedang Regency to maintain the existence of traditional arts. Based on concern and love for their culture, the community continues to make reforms so that the existence of the songah art is maintained and can keep up with the times. This study aims to describe and analyze the creativity and innovation of society in utilizing existing natural resources as an effort to maintain and develop the songah traditional art. Through a qualitative approach and descriptive methods, the researchers reveal the creative process carried out by the people of Citengah Village in maintaining and developing the songah art. This study's data were collected through observation, interviews, and strengthened by a literature review, which was then analyzed using descriptive qualitative techniques. The results showed that the creativity of the people of Citengah Village in maintaining and developing the songah traditional art can be seen in the aspects of natural resource management in the area. The community changed songong, which is a means of blowing fire in a furnace (Sundanese: Hawu), into an art tool called songah (songsong Citengah/songong kabungah). As a musical instrument having no tone, people who are members of the community collaborate songsong with other musical instruments to produce a unique musical composition. The development of the s art cannot be separated from the innovation of the community that collaborates songah with other musical instruments. This has a positive impact on the songah art so that it can be side by side and not less competitive with other traditional arts, including arts originating from abroad. Based on the results of existing research, the development of community's creativity and innovation in maintaining the existence of art needs to be done continuously to anticipate being alienated and the loss of traditional arts.
\end{abstract}

Keywords: creativity; innovation; traditional art; songah

How to Cite: Ridwan, R., Narawati, T., Karwati, U., Sukmayadi, Y. (2020). Creativity and Innovation of Artist in Maintaining and Developing the Songah Tradition Art. Harmonia: Journal of Arts Research And Education, 20(2), 213-222

\section{INTRODUCTION}

Citengah Village is one of the villages in Sumedang Regency which has abundant natural wealth. The local village community takes advantage of the natural resources available to meet various needs such as household utensils, kitchen equipment, crafts, and even art tools as a means of fulfilling aesthetic needs. Besides, the existing natural resources are also managed by the community to support the activities of developing the Village into a Tourism Village.

The process of managing bamboo plants by the community is not done in-

\footnotetext{
Corresponding author:

E-mail: ridwansimon@student.upi.edu
} 
dividually. In fact, in life in this world, humans need each other, including in artistic activities. Through the association of the public with domestic and foreign people, this will impact the emergence of awareness that the traditional arts that are owned should be preserved.

Through the awareness and concern of the people of Citengah Village, efforts to preserve culture are carried out through community empowerment activities, namely forming communities based on art and culture. The community is led by $\mathrm{Ki}$ Madhari as the traditional leader of Citengah Village. Apart from being active in the arts, he is also a craftsman of art objects. The main purpose of the formation of this art is to build the abilities and skills possessed by Ki Madhari and the local community in the fields of crafts and arts.

One of the results of Ki Madhari and the local community's artistic activities is the songah art. This art had lost its existence in the local community until finally, the situation changed again in 2008. Previously, the songah art was not entirely a musical instrument, but was a separate instrument and had its respective functions. Like the songong which is a tool for blowing fire in a furnace (Sundanese: hawu), hatong as a means of calling pigeons which is commonly used in bird racing activities, kokoprak which is a tool to repel birds which are commonly used by farmers. Through revitalization activities carried out creatively by the art community led by Ki Madhari in 2013, the songah art was born and began to exist again as a form of musical performance.

The songah art is currently not widely known by the community. However, the people of Citengah Village believe that if it continues to be developed, the existence of the songah art can still be sustainable. The same thing happened to the patrol music. Research conducted by Sari (2019) shows that there is no doubt that traditional arts are weakening in this global era. However, all of that can be anticipated by the patrol music supporters by making continuous innovation by utilizing technological de- velopments and local customs.

The existence of the instrument songah is inseparable from the habits of the people in exploiting the natural potential, especially in managing bamboo plants. The proximity of local villagers to bamboo plants is due to Indonesia's tropical climate so that bamboo plants thrive. The use of bamboo plants with the advantages of their material characteristics has been used creatively by our society to become household products, interiors, and musical instruments. Therefore, songah is one of the creative works of the people of Citengah Village in exploring the use of bamboo as a musical instrument.

Creativity, according to (Utami, 1999) as a humanistic psychologist, is the experience of expressing and actualizing individual identities concerning oneself, other people, and the environment. In line with this, Hulbeck (1945) states that "creative action is an omposing of one's own whole personality on the environment in an unique and characteristic way." Based on Oxford Advanced Learner's Dictionary (Setiawan, 2016; Wehmeier, 2005), creativity means "involving the use of skill and the imagination to produce something new or a work of art, and having the skill and ability to produce something new, especially a work of art, showing this abilityBased on the above statement, creativity is a unique action that arises because of the interaction of individuals both with themselves and with their surroundings.

Creativity seen from the point of view of psychoanalytic theory is the result of solving problems. According to Freud (2011), creativity emerges as a defense mechanism that is part of the personality. Creative people can easily solve various problems. Based on Freud's theory, creativity can be formed through the family environment, school environment, and community environment. The three environments are related to each other in the process of developing creativity.

From a humanistic point of view, creativity can develop as long as a person is alive and is not limited. In line with this 
statement, Maslow (1954) argues that creativity is a basic instinct so that it becomes a necessity. From the process of creativity, changes are made for the better than before. This can also be seen in the songah traditional art that has changed form, function, and performance.

In this regard, there are several relevant studies. Research conducted by Tjaturrini (2018) explains that innovation efforts in an art form can be made by combining two different aspects of art. Through her research, she found that there is an idiom of the barongsai art originating from China in the music performance of calung lengger. In this context, it appears that the existing art actors try to combine the two cultures (acculturation) in maintaining the existence of the art of Calung Lengger.

In a different context of the study, research conducted by Irianto (2017) explains that changes and various innovations in traditional arts by utilizing technological developments can be carried out to maintain and preserve traditional arts. This is relevant to research conducted by Budi (2017) that explains that the modification of angklung carried out by Sundanese artists on the aspects of scales, game techniques, materials, shapes, and ornaments or accessories is done as an effort to overcome various weaknesses that exist so that the angklung musical instrument becomes better than before. This modification effort was also carried out to overcome the weaknesses of bamboo as the basic material for making angklung.

Research conducted by Setiawan (2016) explains that creativity and innovation in the performing arts are needed as an effort to maintain existing traditional arts. For example, the cultural acculturation between the Sasak ethnic group as the original inhabitants of Mataram city and the ethnic immigrants including Javanese, Balinese, Bugis, Bima, Flores, Chinese, Arabic, and others has been able to maintain the continuity of existing arts. The performing arts include Gamelan Gendang Beleq, Wayang Sasak, Betek Baris Lingsar, Cepung Theater, Cupak Gerantang Thea- ter, and Indonesian dances.

Subaharianto's (2015) research that was conducted using an ethnographic approach explained the importance of the creative involvement of the role of young people based on local culture in the development of existing arts. This is relevant to the research results of Aswoyo \& Sularso (2020) that explain that the concept of role models in festival management resulting from the creativity of the local community turns out to be an important basis in the preservation of traditional arts. Likewise, in different aspects, the research conducted by Jaja (2016) explains that the continuity of traditional arts in West Java is none other than due to real actions were taken by the community and the government together.

Based on existing findings and theories related to community phenomena in developing art, it is necessary to study indepth the creative process carried out by the people of Citengah Village in utilizing bamboo plants to become the traditional art of songah. Apart from that, how do the people of Citengah Village make efforts to innovate so that the art of songah continues to exist in line with the changes in the society.

\section{METHOD}

This research was conducted in Citengah Village, Sumedang Regency, West Java. The subjects of this research are the people of Citengah Village who are members of the community of art actors led by Ki Madhari. The research was conducted using a descriptive analysis method in a qualitative approach. This approach was chosen to provide an in-depth picture of the creative and innovation process carried out by the people of Citengah Village in maintaining and developing the songah art.

The research process is carried out by examining holistically the phenomena that occur in the community of Citengah Village. The data collection process was carried out using direct observation 
techniques and was supported by information obtained from literature reviews and interviews conducted with the chairman and members of the songah art community group. Observations were made to get a real picture of what was happening in the field regarding the condition of the songah art in Citengah Village. Interviews were conducted to obtain information about the views, perceptions, responses, and expectations of the local community regarding the songah art.

The data that has been collected from observations and interviews are then analyzed and strengthened by several related theories obtained from literature reviews. The data analysis technique was carried out qualitatively by describing in detail the results of the analysis of the research data obtained during the research.

\section{RESULT AND DISCUSSION}

\section{Creative Process of the Community of Citengah Village in the Songah Art}

The village is an area that is administratively included in Sumedang Regency, West Java. This area has abundant natural potential and cultural arts that have the value of local wisdom. This is a unique and distinctive feature that will attract the area if it can be managed properly and appropriately by the local community.

Bamboo plants are one of the natural resources that are often found in Citengah Village. Plants have quite a lot of functions and benefits in the life of the Sundanese community, including the people of Citengah Village. The many functions and benefits of bamboo for people's lives, make bamboo plants have physical value and implied a philosophical meaning that can be used as a guide for people's lives, especially the Sundanese people. The Indonesian Minister of Environment in the President Soeharto era (Laras \& Nugraha, 2015; Rosyadi, 2012; I. Setiawan et al., 2017) revealed the concept of bamboo culture which states that Sundanese people are more familiar with bamboo trees, if they want to destroy Sundanese people, then first must destroy the bamboo tree. The habit of using bamboo as a fulfillment of needs in everyday life is then passed on to the next generation to become a culture. Bamboo plants are used to meet various needs, both household needs and aesthetic needs, including in artistic activities.

The use of bamboo plants in artistic activities is not the first time that the community of Citengah Village has done it. Previously, there was the use of bamboo plants which were made into the main material in making housing as seen in the community of the Naga village, the houses of the Baduy tribe, and many more. This is done in addition to taking advantage of the existing natural wealth; the community also believes that bamboo plants are sturdy and strong building materials.

Apart from being the main ingredient in meeting primary needs, bamboo plants have also been widely used in making art tools. It can be seen from the many arts created by people from various regions such as angklung, calung, karinding, calempung from West Java, saluang from Minangkabau, rindik from Bali, Sasando from NTT, and many more.

The Indonesian people and foreign people carry out the use of bamboo plants as an artistic tool. This can be seen from the existence of the art of shakuhachi which is a bamboo musical instrument originating from Japan, the musical instrument of khene from Thailand, the musical instrument of diggerido from Australia, the musical instrument of ocarina from Argentina, and others (Christine, 2016)

Creativity of the community of Citengah Village in utilizing bamboo plants in artistic activities continues to be developed to create the uniqueness of the arts it makes. Society changes Songsong which is one requirement that the original household appliance serves as a fire in the furnace blower (Sundanese: hawu) into a musical instrument known as songah (songsong Citengah/songsong kabungah). The use of songsong as a household tool in everyday life has decreased because people have now switched to using modern equipment. 
The people of Citengah Village carried out the art development effort by forming a songah art community led by $\mathrm{Ki}$ Madhari as pupuhu of Citengah Village. The songah art community has a positive impact and a considerable influence on the preservation and development of the songah art indirectly. Through the use of songsong, the local community has indirectly strengthened the culture in using songsong. This will also have an impact on the development of the village into a tourist village that can go global.

Songah has six kinds of waditra covering big Songsong, small songsong, big hatong, small hatong, kokoprak, and flute. Each waditra has different characteristics and functions. When viewed from the sound source, the instrument of songah belongs to the musical instrument of aerophone. The sound produced by the instrument of songah comes from the resonance of the air. The six waditra can be seen in the image below.

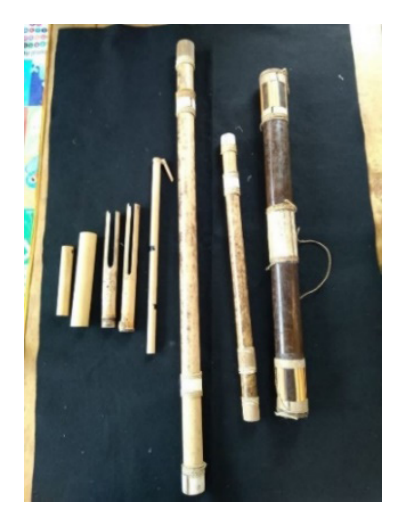

Figure 1. The Musical Instrument of Songah (Source: Personal Documentation)

A big songsong is made with a length of $115 \mathrm{~cm}$ and a diameter of $5 \mathrm{~cm}$. The way to play a big songsong is by blowing it using the technique of vibrating the lips so that the resulting sound resonance is unique. In this musical instrument, the function of the big songong is to act as a goong. The shape of a big songsong can be seen as follows.

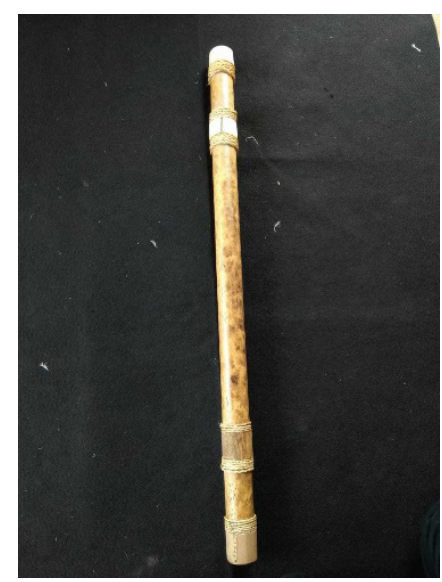

Figure 2. Big songsong

(Source: Personal Documentation)

The sound of the big songsong as mentioned in the previous section, when presented in the musical notation can be seen as follows:

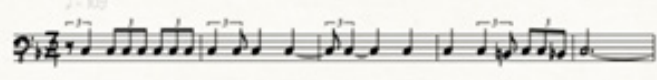

\section{21}

Figure 3. The musical notation of the big songsong

In contrast to the big songsong, the small songsong is made with a length of 75 $\mathrm{cm}$ and a diameter of $3 \mathrm{~cm}$. However, the big songsong and the small songsong have similarities in the way they play, namely by being blown using a resonance technique through lip vibrations. Based on the sound produced, the small songsong functions as a drum. The shape of the small songsong can be seen as follows.

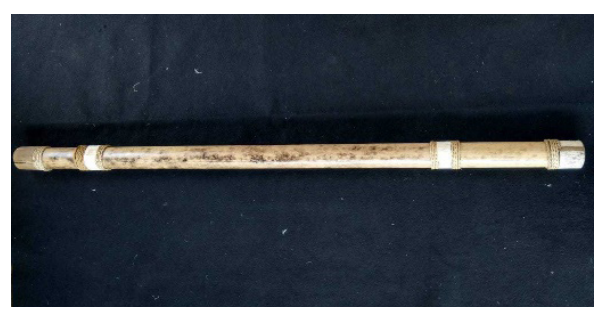

Figure 4. Small songsong

(Source: Personal Documentation) 
When presented in the notation, the sound of the small songsong can look as follows:

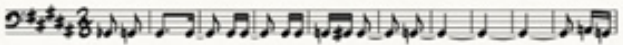 0:}

Figure 5 . The notation of the small songsong

The big hatong is made with a length of $20 \mathrm{~cm}$ and a diameter of $5 \mathrm{~cm}$, while the small hatong is made with a length of $10 \mathrm{~cm}$ and a diameter of $3 \mathrm{~cm}$. The way to play hatong can be done by blowing and opening the lid of the hatong so that it produces a sound that resembles the sound of a bird. The big hatong and the small hatong have the same sound function, namely as a melody. The hatong shape can be seen as follows.

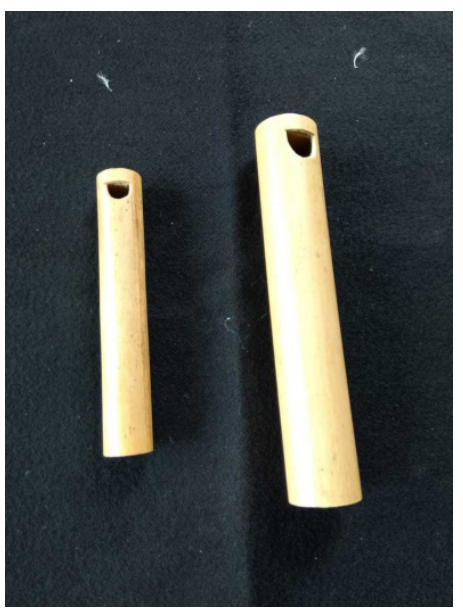

Figure 6. Hatong (Source: Personal Documentation)

Even though they have the same function as a melody, the sound produced from the big hatong and the small hatong has differences, so that when presented in a notation it can be seen as follows.

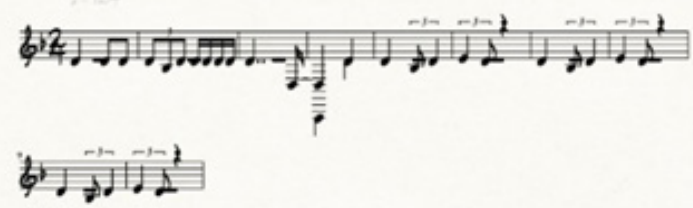

Figure 7. The notation of the big hatong

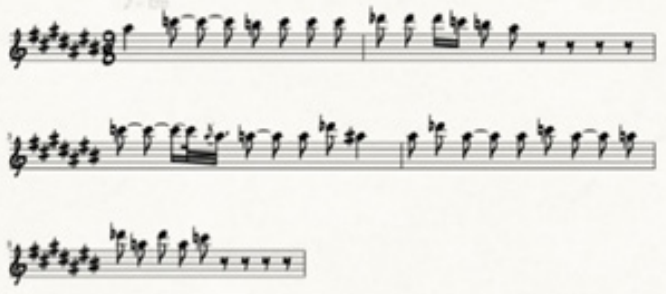

Figure 8. The notation of the small hatong

Unlike other waditra, kokoprak has no size requirement. Either in length or width. Kokoprak in the songah art serves as a regulator of the rhythm of a song or work repertoire (Simon, 2016). The shape of the kokoprak can be seen as follows.

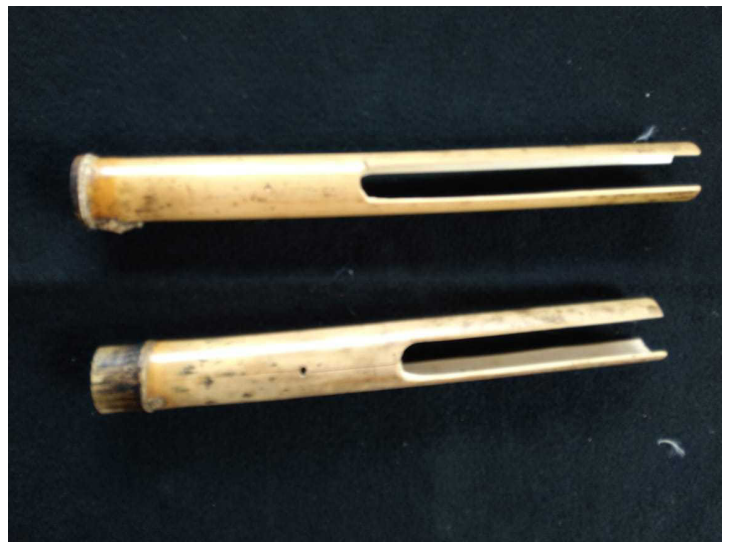

Figure 9. Kokoprak (Source: Personal Documentation)

The sound of the kokoprak waditra, when presented in musical notation, can be seen as follows:

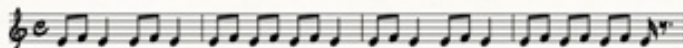

Figure 10. The notation of Kokoprak

The songah art was initially limited to songsong as a cooking tool that did not have a tone in the sound. But in the end, it was collaborated with other musical instruments to form a unique musical composition. The creativity possessed by the art community in Citengah Village in utilizing bamboo plants to become a musical instrument is a form of application of cognitive flexibility that is owned by each individual. This is marked by the beha- 
vior of individuals who can adapt to the circumstances of their environment, as well as the ability to change their ways of thinking in dealing with a problem. This is in line with what Dariyo (2008) expressed that cognitive flexibility is an individual's ability in a thought process characterized by fluency, flexibility, originality, and elaboration or developing ideas in solving problems. Like when people change songsong as a tool for cooking into an art that can be used to satisfy aesthetic needs. Besides, the development carried out by the community towards the songah art can also have an impact on cultural inheritance and village development through various community innovations that are applied to the songah art.

\section{Innovation in the Songah Art}

The development of the times and the dynamic characteristics of society transform an inevitable reality. The changes that occur cannot be separated from the role of community creativity in facing the challenges of the dynamics of life that continues to develop. In the context of the people of Citengah Village, the songah art is one proof of the people's creativity in transforming the shape and function of songsong (household appliances) to become songah (the musical instrument) to fulfill its aesthetic needs.

Transformation is a process of changing from one form to another which still resembles or is completely different from the original condition. In the field of art and culture, changes in the transformation process can be seen from the aspects of function and content both horizontally and vertically, which still show the identity of a culture (Rosana, 2017; Parmadie, et al., 2018).

According to Leprianida (2009), transformation is a scientific concept as an analytical tool in understanding the world. One of the supporting factors for change in culture is the development of the times. Transformation is usually carried out to preserve local culture so that the next generation can enjoy it.
Historically the bamboo music known to the Sumedang people is angklung buncis. Performances are usually performed in the Sumedang Larang palace on special occasions such as welcoming guests, traditional ceremonies, and other major palace events. Therefore, songah in Citengah village is one of the musical instruments created and developed by the community as an effort to adapt to environmental changes and the demands of the need for expression and artistic creation.

Along with the times, the people of Citengah Village changes the songah art performance of traditional to entertainment functions without abandoning the values contained in it. The people who are members of the art community in Citengah Village have combined and collaborated on the songah art using traditional musical instruments and modern musical instruments such as guitars, drums, and others. Besides, since then this art community has started to present popular songs, especially Sundanese pop songs. In this context, it shows that the innovation process carried out has led to the process of acculturation in the songah art.

According to Nardy (2012) and Putra (2017), acculturation is a combination of two harmonious and peaceful cultures that occur in life. This states that acculturation is the union of two or more cultures so that a new culture can be formed without eliminating the values contained in the old culture.

Until now, the songah art in Citengah village continues to be developed and updated, both in terms of arrangement and the variety of songs it performs. So that when this village was chosen as one of the "tourist villages" in the Sumedang Regen$\mathrm{cy}$, the performance of the songah art became one of the attractions for tourists who came from within the country and abroad. As stated by Rogers (1983) that innovation is an idea of new objects and practices for individuals who own it. Relevant to this statement, what has been done by the art community in Citengah Village is one of the efforts to preserve the songah art so that 
it exists and is maintained.

\section{The Process of the Songah Art Preserva- tion}

Efforts to preserve the songah art among the people of Citengah Village are carried out because the art contains local wisdom values such as a sense of togetherness of "silih asah, silih asih, silih asuh", humble, and willingness to sacrifice as relevant to the Sundanese philosophy (Simon, 2016). There are six strategies carried out by the people of Citengah Village in preserving the songah art. The six strategies are an extension of the word "SONGAH" which means training centers, organizations, nationalization, growing, appreciation, and entertainment. In detail, the existing conservation strategies can be explained as follows.

\section{Training Center}

The training center is one of the efforts made by the art community of songah through learning. This activity is carried out in an integrated manner as part of a tour package that provides an opportunity for visitors/tourists to try to play the songah art directly. Through this activity, the participants interactively and actively participate in learning to play the instrument of songah in a relatively short time.

When learning songah, the participants did not only learn the techniques and practice playing the musical instrument. However, it also teaches the aesthetic and ethical aspects of the songah art and some knowledge, skills, and values related to the norms of life that apply in society. The efforts made by the people who are members of the art community in Citengah Village seem relevant to the results of Sukmayadi and Masunah's (2020) research conducted in Kampung Naga that teaching carried out through oral traditions and demonstrations can be an effort of cultural heritage.

\section{Organization}

The formation of an art community in Citengah Village indirectly supports government programs in community empowerment activities to improve welfare (Ridwan \& Surya, 2018). This is in line with the mandate set out in The Law of the Republic of Indonesia Number 11 of 2009 regarding social welfare.

The songah art community in the Citengah village formed based on Rurukan of Nabawadatala tradition. Rurukan is the forum for responding to various problems related to ideas, thoughts, and suggestions to develop the culture of Citengah Village. The activities carried out by this rurukan tradition include (1) collaboration with the Youth Organization of Citengah Village, (2) fostering the art of songah, (3) training and developing health methods, and (4) practicing alternative health methods.

The community's coaching activity towards the art of songah is not only a performance art that can be enjoyed by local people. However, it can develop more widely because it has also been included in cultural tourism activities both nationally and internationally.

\section{Nasionalization}

Nationalization is a conservation strategy carried out by the art community in Citengah Village in introducing the songah artto a wider area. This strategy has even encouraged the involvement of the music community in Citengah Village in international scale events. On a national scale, the songah art has appeared at the Sumedang Regency Cultural Festival. In international events, the songah art has appeared at the 2019 Paraglidding World Championship Festival with 15 other types of arts.

\section{Growing}

Growth is a strategy of the Citengah Village community in sustainably developing the songah art so that it remains sustainable. The efforts that have been made are such as making innovations in every show while maintaining its uniqueness. The uniqueness becomes important because the more unique an art is, the more people are curious about it, so they will find out about 
it (Raka, n.d.).

In addition to innovating, the art community in Citengah Village also strives to utilize existing technology to develop and preserve the songah art. This effort is done by recording music performances of songah which will then be uploaded on social media to be watched by the wider community. This effort is not only effective in introducing the songah art but also as a promotional medium for tourists.

\section{Appreciation}

Appreciation is a strategy of the art community in Citengah Village to increase public understanding of the songah art. The strategy carried out by this art community is by increasing the number of performance activities and conducting learning through training activities. This includes performances and direct involvement in training activities for visitors who come to Citengah Tourism Village.

\section{Entertainment}

The function of art as entertainment is one of the characteristics of art today. Therefore, since the emergence of the songah art until now, the art community in Citengah Village always strives to develop its arts from various aspects to entertain the supporting community. This effort is carried out by creatively developing the musical arrangements, choosing the types of songs, and the form of performances with the support of various innovations relevant to the characteristics and uniqueness of the songah traditional art.

\section{CONCLUSIONS}

The songah art is a form of creative work from the art community in Citengah Village. Changes in the times and the development of the existing society encourage the people in this village to change and develop songsong which was originally only a household tool into a musical instrument. Various innovations and changes are continuously carried out so that the art of songah is known by the people of Citengah
Village and the wider community. Even as an effort for the welfare of the people of Citengah Village, this art is also one of the performers of interesting performances for tourists who come to Citengah Tourism Village.

The songah art can survive and exist until now because the existing art community has implemented various strategies, such as: (1) establishing a training center; (2) providing organizational guidance; (3) spreading over a wider area; (4) cultivating and developing the songah art continuously; (5) increasing community appreciation efforts for the songah art; and (6) packaging the songah performances into interesting entertainment.

\section{REFERENCES}

Abdul, M. I. (2017). Desa Citengah. Sumedang Tandang BPS Kabupaten Sumedang. http://sumedangtandang.com/direktori/detail/desacitengah.htm

Aswoyo, J., \& Sularso, S. (2020). The Concept of Panutan in Governance Festival Lima Gunung in Magelang Central Java Indonesia. Harmonia: Journal of Arts Research and Education, 20(1), 1-9.

Christine, B. (2016). Ternyata Bambu Bisa DisulapJadi 10 Alat Musik Cantik. https:/ / tentik.com/ternyata-bambu-bisa-disulap-jadi-10-alat-musikcantik-ini/\#: :text=Ohe hano ihu adalah alat,ini ditiup dengan menggunakan hidung.

Dariyo, A. (2008). Psikologi Perkembangan Dewasa Muda. Jakarta: PT. Grasindo.

Freud, S. (2011). Interaksi dan Motivasi Belajar Mengajar. Jakarta: PT Raja Grafindo Persada.

Hulbeck, C. R. (1945). Oilpaintings, Watercolors, Drawings. Feigl Gallery.

Irianto, A. M. (2017). Kesenian Tradisional Sebagai Sarana Strategi Kebudayaan di Tengah Determinasi Teknologi Komunikasi. Nusa: Jurnal Ilmu Bahasa dan Sastra, 12(1), 90.

Jaja, D. (2016). Pengaruh Kebijakan Pemer- 
intah dan Kreativitas Seniman Terhadap Kesenian Tradisional Jawa Barat. Makalangan, 7(1), 34-39.

Khotimah, K. (2017). Strategi pengembangan destinasi pariwisata budaya (Studi kasus pada kawasan Situs Trowulan sebagai Pariwisata Budaya Unggulan di Kabupaten Mojokerto). Jurnal Administrasi Bisnis, 42(1), 56-65.

Laras, J. A., \& Nugraha, A. (2015). Angklung Tradisional Sunda: Intangible, Cultural Heritage Of Humanity, Penerapannya Dan Pengkontribusiannya Terhadap Kelahiran Angklung Indonesia. 2(1), 1-23.

Leprianida. (2009). Studi Pemikiran Kuntowijoyo Tentang Ilmu Sosial Profetik. $1-60$.

Maslow, A. (1954). Motivation and Personality. Harper \& Row.

Nardy, H. (2012). Persatuan Dua Budaya. Permana Offset.

Parmadie, B., Kumbara, A. N. A., Wirawan, A. B., \& Sugiartha, I. G. A. (2018). Pengaruh Globalisasi dan Hegemoni Pada Transformasi Musik Dol di Kota Bengkulu. Mudra Jurnal Seni Budaya, 33(1), 67-75.

Putra, W. I. (2017). Proses Akulturasi Masyarakat Paser Dan Masyarakat Transmigran Jawa Di Kecamatan Long Kali Kabupaten Paser Kalimantan Timur. Phinisi Integration Review, 1(1), 1-14.

Raka, R. (N.D.). Perjalanan Dunia Baru. Visual Art, 4(1), 180548.

Richards, G., \& Wilson, J. (2006). Developing creativity in tourist experiences: A solution to the serial reproduction of culture?. Tourism management, 27(6), 1209-1223.

Ridwan, R., \& Surya, C. (2018). Pemberdayaan masyarakat desa dalam mengembangkan ekonomi kreatif di desa citengah kabupaten sumedang. Jurnal Riset Akuntansi Kontemporer, 10(1), 28-33.

Rosana, E. (2017). Dinamisasi Kebudayaan dalam Realitas Sosial. Al-Adyan: Ju- rnal Studi Lintas Agama, 12(1), 16-30.

Rosyadi, R. (2012). Angklung: dari Angklung Tradisional ke Angklung Modern. Patanjala, 4(1), 25-38.

Sari, J. R. (2019). Musik Patrol Dan Identitas Sosial Gaman Di Surabaya. Resital: Jurnal Seni Pertunjukan, 18(3), 168-178.

Setiawan, B. (2016). Kreativitas Dan Inovasi Seni Pertunjukan Sebagai Jembatan Membangun Multikultur: Studi Kasus Masyarakat Kota Mataram. Jurnal Penelitian Sejarah Dan Nilai Tradisional, 23(1), 1-14.

Setiawan, I. (2017). Dokumenter TV:“Udjo \& Saung Angklung" Sebagai Manifestasi Budaya Sunda. ProTVF, 1(1), 89-104.

Simon, R. (2016). Transformasi Nilai Kebersamaan Dalam Musik Songah. Metodik Didaktik, 10(1), 23-36.

Subaharianto, A., Tallapessy, A., \& Setiawan, I. (2015). Menyerbukkan Kreativitas: Model Pengembangan Kreativitas Kaum Muda dalam Sanggar Seni Using sebagai Penopang Budaya Lokal dan Industri Kreatif di Banyuwangi. Jember: Universitas Jember

Sukmayadi, Y., \& Masunah, J. (2020). Organizing Bandung Isola Performing Arts Festival (BIPAF) As A Market of Innovative Performing Arts in Indonesia. Harmonia: Journal of Arts Research and Education, 20(1), 47-57.

Tjaturrini, D. (2018). Calengsai : Kreativitas dan Inovasi Pekerja Seni dalam Mempertahankan Kesenian Tradisional. Ilmiah Lingua Idea, 9(2), 1-12.

Undang-Undang Republik Indonesia Nomor 11 Tahun 2009 Tentang Kesejahteraan Sosial. (2009).

Upaja, B. D. S. (2017). Modifikasi Angklung Sunda. Resital: Jurnal Seni Pertunjukan, 18(1), 43-52.

Utami, M. (1999). Kreativitas dan Keberbakatan. Jakarta: Gramedia Pustaka Utama.

Wehmeier, S. (2005). Oxford Advanced Learner's Dictionary. Seventh edition. Oxford University Press. 